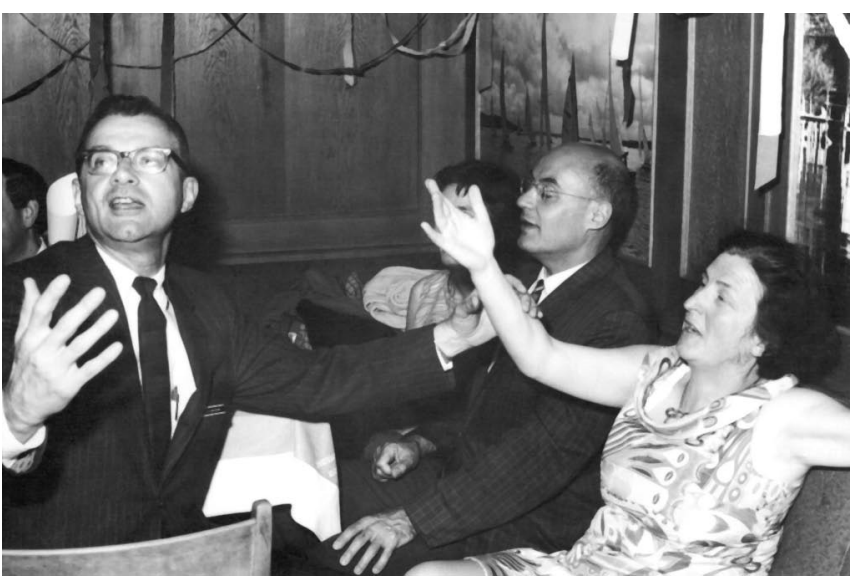

Three Atlantic City experiences stand out in my memory. In 1948, I attended the presentation by Philip S. Hench of the Mayo Clinic, who first introduced cortisone treatment of rheumatoid arthritis. It took place in one of the ballrooms of the old Haddon Hall Hotel, and the big room was packed. Before your eyes, there were pictures of formerly crippled, immobile patients who got up and walked. It was like a biblical miracle. At the conclusion of the 10-minute talk, the audience stood and applauded. Everyone felt that they had witnessed something historic - and they had!

My second memory concerns the first paper I ever gave at the Atlantic City meetings. It was entitled "The antidiuresis of quiet standing," and it summarized experiments on myself, Arnold Relman, and other fellow residents and interns at Yale. A consequence of the antidiuresis of standing, of course, was the diuresis that occurs when lying down. In the audience was Henry Christian, then chief of Medicine at the Peter Bent Brigham Hospital, the founder of the AFCR, and one of the original Young Turks. He raised his hand to make the first comment during the question period. As he rose to his full height of more than six feet, his great bald head gleaming in the light, I grew more nervous. "Now

\section{Figure 1}

Typical celebrants at the conclusion of an $\mathrm{ASCl}$ meeting in Atlantic City in the 1950s. Left to right: Franklin H. Epstein (later William Applebaum Professor of Medicine at Harvard Medical School and Physician-in-Chief, Beth Israel Deaconess Hospital, Boston), Alexander Leaf (later Jackson Professor of Medicine at Harvard Medical School and Physician-in-Chief, Massachusetts General Hospital), and Sheila Sherlock (later Dame Sheila Sherlock and Physician-in-Chief, Royal Free Hospital, London). The face of Leaf's wife, Barbara, is hidden by Sherlock's hand.

I finally understand," he rumbled, "why I have to get up to urinate only two hours after lying down."

In my third memory, I am riding an elevator in the Haddon Hall Hotel. The elevator car is crowded with medical academics and would-be academics. I am standing next to a large, rumpled, distinguished-looking man, whom I recognize immediately as William Castle, professor of Medicine at Harvard and director of the famous Thorndike Memorial Laboratory at the Boston City Hospital. The elevator stops at my floor, and I prepare to get out. Before I do, the large man grasps my hand and says, "Dr. Epstein, Bill Castle. I enjoyed your talk." I mumble thanks and leave the elevator on a cloud. What a nice man! He made my day, my week, my year!

What contributed to the magic of the Atlantic City meetings? Partly the sense that the presentations were the best that American academic medicine could produce. Partly that the presentations were taken seriously and questioned critically. Partly that professors, fellows, and neophytes walked and sunned themselves on the same Boardwalk and even talked to each other. They talked with each other! That is a tradition of the Young Turks that is worth preserving!

Address correspondence to: Franklin H. Epstein, Department of Medicine, Renal Division, Dana Building, Suite 517, Beth Israel Deaconess Medical Center, 330 Brookline Avenue, Boston, Massachusetts 02215, USA. Phone: (617) 667-4104; Fax: (617) 667-5276; E-mail: fepstein@bidmc.harvard.edu.

\title{
The American Society for Clinical Investigation - the first 100 years
}

\author{
Paul A. Marks \\ Cell Biology Program, Memorial Sloan-Kettering Cancer Center, New York, New York, USA.
}

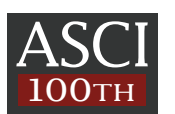

The annual Atlantic City meeting of the Young Turks was an exciting event - an opportunity to hear great science, to explore career opportunities, and to meet and make friends. Though the 1950s, '60s, and '70s, the meetings remained relatively intimate, broadly covering the best in medicine and constantly growing until the participants outgrew the Atlantic City venue to eventually spawn the numerous specialty annual meetings that we have today.

I attended my first meeting of the Young Turks (the ASCI) in 1953. As usual, it was held the first week in May in Atlantic City. There were at least three aspects of the Young Turks meetings

Conflict of interest: The author has declared that no conflict of interest exists. Citation for this article: J. Clin. Invest. 118:1223-1224 (2008). doi:10.1172/JCI34805. in Atlantic City that were important, indeed critical, to those of us aspiring to careers in academic medicine. The first was to be invited by your postdoctoral mentor - your first experience, and it truly was an experience - and remained so even as you grew old enough to get to an annual meeting on your own. After the first meeting, it became a required right of passage to attend annually. 
The second was to submit an abstract and have it accepted for presentation at the plenary session. The third, and perhaps the most important - certainly the most intensely enjoyable - was to save plenty of time to talk to colleagues and explore potential opportunities for positions with the older, established attendees. Schmoozing was part of the opportunity of being at the meetings - and, of course, you frequently heard impressive science. It was a major learning experience, made possible in part by the intimacy of the meeting and its site.

In 1953 all the meetings would be held in the Haddon Hall Hotel. The Young Turks would meet in the ballroom, and this was followed by the meeting of the Old Turks (the AAP) in the Vernon Room - with probably fewer than 1,000 total attendance. I do not remember the exact year, but it was a wrenching experience when two realizations overwhelmed the Young Turks. First, the attendance was so large that the meetings had to be moved to the Convention Hall across the Boardwalk from Haddon Hall - a loss of intimacy, but not too bad. Second, the number of abstracts submitted increased annually, and to provide a greater opportunity for more involvement of the good science, simultaneous section meetings were scheduled - none in conflict with the plenary sessions.

The presentations themselves were generally very impressive, well rehearsed, and almost always precisely ten minutes in length (with five minutes for questions). The rule was that slides should be clear, with just enough on a slide for one to grasp its content.
In fact, it was de rigueur to show a slide that had so much material as to be unintelligible.

Certainly, a most exciting and rewarding aspect of these meetings was the opportunity to relax and discuss our science, our careers, and our colleagues.

The hallmark of the Atlantic City meetings was not only a fine level of scientific presentations, but also the sense of intimacy that we experienced as young professionals focused on the best in biomedical sciences with colleagues who shared the same value systems with the same competitive spirit. Ideas were clearly about people, places, and scientific questions. Collaborations were established and above all friendships that have lasted through decades of our careers.

It is difficult and wrong to stand in the way of growth and progress. When in the 1970 s the meetings were moved initially to Washington, DC, and subsequently to other venues, the quality that made the Young Turks' annual sojourn so special for so many of us was to some extent diminished. The biomedical enterprise has continued to flourish and grow - discoveries unthinkable even two decades ago are occurring almost daily. We have memories, but the biomedical sciences are much more exciting today!

Address correspondence to: Paul A. Marks, Cell Biology Program, Memorial Sloan-Kettering Cancer Center, 1275 York Avenue, New York, New York 10065, USA. Phone: (212) 639-6568; Fax: (212) 639-2861; E-mail: marksp@mskcc.org.

\title{
Homage to Atlantic City
}

\author{
Lloyd H. Smith Jr.
}

Department of Medicine, UCSF, San Francisco, California, USA.

\section{ASCI annual spring meetings that were held in Atlantic City for two generations prior to 1977 and consider whether lessons remain from those past experiences.}

History is more or less bunk.

$$
\text { -Henry Ford (1) }
$$

The present state of things is the consequence of the former, and it is natural to inquire what were the sources of the good that we enjoy, or the evil that we suffer. If we act only for ourselves, to neglect the study of history is not prudent; if we are entrusted with the care of others, it is not just.

-Samuel Johnson (2)

Viewed objectively, Atlantic City was and is merely a somewhat squalid excrescence on the New Jersey coast. But for more than two generations of academic internists (prior to 1977), it symbolized the highest aspirations of our profession. The evocative power of that symbol is now fading rapidly both with and within the memory of my generation. Does this symbol remain now only as "Atlantis City," largely a fable of a submerged past reality? Do lessons from that past experience remain valid for us yet? In brief, who was correct - Henry Ford or Samuel Johnson?

Conflict of interest: The author has declared that no conflict of interest exists. Citation for this article: J. Clin. Invest. 118:1224-1227 (2008). doi:10.1172/JCI34757.
What was the Atlantic City of the past? Each will have his or her personal memories, now viewed in the vivid retrospectroscope of our youth. Regrettably, the telomeres of those memories erode away with those of their hosts, but much remains. In odd ways, the setting could be considered to be ideal for a scholarly gathering. Distractions were few - Chalfonte-Haddon Hall, Captain Starn's, Hackney's Restaurant, the Jockey Club, Brighton Punch, watching birds at Brigantine National Wildlife Refuge and even more interesting "specimens" close at hand. Even the difficulty in getting there insured a sense of productive isolation. The famed Boardwalk served as a limiting membrane along which, in the course of a day, one could view and/or engage all of the currently key participants in American academic internal medicine. The Steel Pier was sufficiently crowded to create a sense of participatory theater and sufficiently uncomfortable to inhibit somnolence. All in all, a very improbable setting, but one in which the intellectual and social cohesion of our profession was annually renewed and reinvigorated. Various of the components of these past spring meetings can be teased apart, but such a dissection arbitrarily diminishes the total impact of that unique Atlantic City experience. 